\title{
Macrofaunal Functional Diversity Provides Resilience to Nutrient Enrichment in Coastal Sediments
}

\author{
Emily J. Douglas, ${ }^{1}$ Conrad A. Pilditch,${ }^{1 *}$ Casper Kraan, ${ }^{2,4}$ \\ Louis A. Schipper, ${ }^{1}$ Andrew M. Lohrer, ${ }^{2}$ and Simon F. Thrush ${ }^{3}$
}

\begin{abstract}
${ }^{1}$ School of Science, University of Waikato, Private Bag 3105, Hamilton 3240, New Zealand; ${ }^{2}$ National Institute of Water and Atmospheric Research, P.O. Box 11-115, Hamilton 3251, New Zealand; ${ }^{3}$ Institute of Marine Science, University of Auckland, Private Bag 92019, Auckland 1142, New Zealand; ${ }^{4}$ Present address: Department of Functional Ecology, Alfred Wegener Institute Helmholtz Centre for Polar and Marine Research, Am Handelshafen 12, 27570 Bremerhaven, Germany
\end{abstract}

\begin{abstract}
The degradation of ecosystems is often associated with losses of large organisms and the concomitant losses of the ecological functions they mediate. Conversely, the resilience of ecosystems to stress is strongly influenced by faunal communities and their impacts on processes. Denitrification in coastal sediments is a process that may provide ecosystem resilience to eutrophication by removing excess bioavailable nitrogen. Here, we conducted a large-scale field experiment to test the effect of macrofaunal community composition on denitrification in response to two levels of nutrient enrichment at 28 sites across a biologically heterogeneous sandflat. After 7 weeks of enrichment, we measured denitrification enzyme activity (DEA) along with benthic macrofaunal community composition and environmental variables. We normalised treatment site specific DEA values by those in ambient sediments $\left(\mathrm{DEA}_{\mathrm{CN}}\right)$ to reveal the underlying response across the heterogeneous landscape. Nutrient enrichment caused reductions in $D_{E A} A_{C N}$ as well as functional changes in the community; these were both more pronounced
\end{abstract}

under the highest level of nutrient loading (on average $\mathrm{DEA}_{\mathrm{CN}}$ was reduced by $34 \%$ ). The degree of suppression of $\mathrm{DEA}_{\mathrm{CN}}$ following moderate nitrogen loading was mitigated by a key bioturbating species, but following high nitrogen loading (which reduced the key species density) the abundance and diversity of other nutrient processing species were the most important factors alleviating negative effects. This study provides a prime example of the context-dependent role of biodiversity in maintaining ecosystem functioning, underlining that different elements of biodiversity can become important as stress levels increase. Our results emphasise that management and conservation strategies require a real-world understanding of the community attributes that facilitate nutrient processing and maintain resilience in coastal ecosystems.

Key words: denitrification; benthic community; nutrient processing; eutrophication; enzyme assay; intertidal; functional traits; sandflat.
Received 28 July 2016; accepted 13 December 2016;

Electronic supplementary material: The online version of this article (doi:10.1007/s10021-017-0113-4) contains supplementary material, which is available to authorized users.
Authors contributions EJD, CAP, SFT, CK and AML designed the study and performed field research. EJD performed laboratory analyses with input from LAS. EJD and CAP analysed data, EJD wrote the manuscript with assistance from CAP and input from SFT, CK, AML and LAS. *Corresponding author; e-mail: c.pilditch@waikato.ac.nz 


\section{INTRODUCTION}

Enrichment of the ocean through anthropogenic alteration of the nitrogen cycle is leading to degradation of marine ecosystems and the services they provide (Nixon 1998). This occurs because nitrogen is essential for primary production and its oversupply in (generally) nitrogen-limited systems can cause blooms of algae, increases in organic matter, alteration of nutrient ratios and changes to habitats, communities and food webs (Vitousek and others 1997). Most of the terrestrial nitrogen received by the marine environment is removed through denitrification in coastal sediments (estimated up to $80 \%$ ), a natural ecosystem process that removes bioavailable nitrogen (Galloway and others 2003). Denitrification $\left(D_{\mathrm{N}}\right)$ can therefore provide resilience to eutrophication, which is recognised as a global threat to the functioning of coastal ecosystems and the goods and services they provide (Vitousek and others 1997; Laursen and others 2002).

Benthic macrofauna, such as bivalves and polychaetes, play a critical role in coastal marine nitrogen cycling. Particle and water transport related to feeding and movement activity (that is, bioturbation) promotes transport of nutrients and oxygen throughout the sediment profile enhancing rates of nitrogen transformation (Kristensen and others 1985, 1991; Pelegri and others 1994; Gilbert and others 1998; Webb and Eyre 2004; Laverock and others 2011). In sediments with an oxic layer and low water column nutrient concentrations, nitrification and $D_{\mathrm{N}}$ are often coupled (Sloth and others 1995; Seitzinger and others 2006). The distinct oxygen conditions these processes require (that is, presence of oxygen for nitrification and anoxia for $D_{\mathrm{N}}$ ) mean that the interface between the oxic and anoxic sediments is an important site for coupled $D_{\mathrm{N}}$. The activities of benthic macrofauna cause this interface to be dynamic in space and time (Volkenborn and others 2010, 2012), enhancing coupled $D_{\mathrm{N}}$ (Stief 2013). Moreover, bioturbation can also enhance un-coupled $D_{\mathrm{N}}$ by increasing the supply of nitrate to sediments from the water column (Kristensen and others 1991; Nogaro and Burgin 2014). However, if macrofauna are negatively affected by nutrients and/or other stressors, their positive influence on $D_{\mathrm{N}}$ will be diminished.

Degradation of biodiversity through loss of species can reduce an ecosystem's ability to withstand stress or adapt to changing conditions (Villnäs and others 2013). Species loss can be deleterious to key ecosystem processes contributing to feedback loops that invoke changes in community and overall ecosystem function (Thrush and others 2006, 2014). Given the complex interaction between bioturbating macrofauna and nitrogen cycling and that species with traits relevant to nutrient processing will vary in their sensitivity to stress (that is, response diversity) (Elmqvist and others 2003; Hewitt and others 2010; Mori and others 2013; de Juan and others 2014), nonlinear responses to losses in biodiversity and ultimately resilience are likely (Naeem and others 1994; Chapin and others 2000). Identification of the elements of macrofaunal diversity that contribute to $D_{\mathrm{N}}$ is necessary to understand the potential ecosystem response to nutrient oversupply and to adequately conserve the necessary aspects of biodiversity. These elements include both local- (alpha), and landscapescale (gamma) diversity that contribute to the overall heterogeneity of communities (beta diversity), which can provide a measure of ecosystem stability (Doak and others 1998; Thrush and others 2008). As diversity and density of marcofauna decrease, $D_{\mathrm{N}}$ rates are also likely to decrease, which may in turn further intensify eutrophication impacts, creating a strong feedback (Loreau and others 2001; Folke and others 2004; Hewitt and others 2010; Hewitt and Thrush 2010).

Nitrogen loading to coastal ecosystems is increasing globally (Galloway and others 2008), and there is a pressing need to understand how it alters $D_{\mathrm{N}}$ and interactions with macrofaunal diversity in real-world settings. Although field studies have quantified $D_{\mathrm{N}}$ in a range of coastal habitats (for example, Piehler and Smyth 2011; Eyre and others 2013; Foster and Fulweiler 2014) they do not make linkages to macrofauna diversity or the diversity response to nutrient stress, and the consequences for $D_{\mathrm{N}}$ are absent. Similarly, despite a considerable amount of research examining aquatic sediment nitrogen cycling (reviewed by Huettel and others 2014), and much highlighting the importance of macrofauna [reviewed by Stief (2013)], studies have so far not been able to address potential feedbacks between biodiversity and stressors. To date, nutrient enrichment field experiments have tested the responses of macrofaunal communities (Morris and Keough 2003; Posey and others 2006; Fitch and Crowe 2012), whereas others have measured effects on ecosystem functions including $D_{\mathrm{N}}$ (Koop-Jakobsen and Giblin 2010; Oakes and others 2011; Vieillard and Fulweiler 2012), but no study has combined the two and assessed the role of macrofauna in $D_{\mathrm{N}}$ response to nutrient enrichment.

We simulated eutrophication in situ using sediment nutrient enrichment in experimental plots 
across a sandflat with a heterogeneous landscape of macrofaunal community abundance and diversity. The study focused on two species of shellfish (Austrovenus stutchburyi and Macomona liliana) recognised as key species for nutrient processing (Thrush and others 2006; Sandwell and others 2009; Jones and others 2011; Pratt and others 2013; Thrush and others 2014), as well as 46 other species with traits important for nutrient processing (Greenfield and others 2016). We used denitrification enzyme activity (DEA) assays to provide an index of nutrient processing and nitrogen removal; a proven method for comparisons of denitrification activity in aquatic systems that permits large sample sizes (Barnes and Owens 1998; Livingstone and others 2000; Bernot and others 2003; Wall and others 2005; Teixeira and others 2010; Bruesewitz and others 2011; Jones and others 2011). We expected treatments that caused substantive increases in pore water ammonium $\left(\mathrm{NH}_{4}{ }^{+}\right)$concentrations would be detrimental to the diversity of nutrient processing macrofauna (Pearson and Rosenberg 1978; Gray and others 2002), leading to reductions in DEA. Alternatively, increased pore water $\mathrm{NH}_{4}{ }^{+}$ concentrations could enhance DEA via coupled $D_{\mathrm{N}}$ provided surface sediment remained oxygenated by macrofauna and/or in permeable sediments by advective pore water flushing due to physical processes (Huettel and others 2014).

\section{Methods}

\section{Experimental Design}

Twenty-eight sites across a 300,000 $\mathrm{m}^{2}$ intertidal sandflat in the Kaipara Harbour were selected based on a macrofauna community survey at the study site (Kraan and others 2015) and an analysis of species functional traits that characterise life history, morphology and behaviours that influence sediment biogeochemistry and stability (Greenfield and others 2016). From Greenfield and others, we identified a functional group of 46 species that possessed traits that influence sediment biogeochemistry (for example, deposit feeding, free mobility and burrow building) and therefore are important for nutrient processing. The selected sites encompassed a spectrum of abundance and species richness of this functional group as well as sediment properties (Table 1) to maximise the variation in nutrient processing capacity. The experiment ran for 7 weeks and at each site, 1 procedural control and 2 nutrient enrichment treatment plots $(1 \times 1 \mathrm{~m})$ were established in a $5 \times 5 \mathrm{~m}$ area by adding slow release fertiliser (or pea gravel for controls) buried in the sediments. Fertiliser [Nutricote ${ }^{\circledR}$ N (70 days, 40-0-0 N:P:K)] was applied to each plot in a series of 20 evenly spaced 3-cm-diameter $15-\mathrm{cm}$-deep holes made in the sediment using a hand-held corer. Each hole received an equal volume of fertiliser (or pea gravel) and the intact sediment core plugs were replaced immediately to minimise disturbance to the sediment (see Douglas and others 2016 for details). We considered the control plots to be representative of ambient sediments because less than $2 \%$ of the plot area was impacted and previously; with a similar level of disturbance, we found no procedural effects on intertidal macrofaunal community composition, benthic respiration, nutrient fluxes and primary production when sampled after 4-7 days (Gladstone-Gallagher and others 2014, 2016). Moreover, photographs of plots taken four and 7 weeks after disturbance indicated no trace of coring, even in plots containing seagrass. Application rates (medium $150 \mathrm{~g} \mathrm{~N} \mathrm{~m}^{-2}$, high $600 \mathrm{~g} \mathrm{~N} \mathrm{~m}^{-2}$ ) were based on a literature review of previous enrichment experiments and resulted in significantly elevated pore water $\mathrm{NH}_{4}{ }^{+}$ concentrations for at least 7 weeks in surface $(0-$ $2 \mathrm{~cm}$ ) and deeper $(5-7 \mathrm{~cm})$ sediments (Table 1; Douglas and others 2016).

\section{Sample Collection and Analyses}

All sampling was conducted on March 17, 2014, 7 weeks after fertiliser enrichment. For DEA analyses, five sediment cores $(5 \mathrm{~cm}$ depth, $5.3 \mathrm{~cm}$ dia.) were collected from each plot, pooled, transported on ice to the laboratory, kept at $4^{\circ} \mathrm{C}$ and analysed within $48 \mathrm{~h}$ of collection. Prior to conducting assays, samples were brought to room temperature $\left(20^{\circ} \mathrm{C}\right)$. DEA assays were used as an index of $D_{\mathrm{N}}$ to give a relative measure of sediment nutrient processing and nitrogen removal capacity. DEA assays were conducted using the chloramphenicolamended acetylene inhibition technique (Tiedje and others 1989; Groffman and others 1999; Bruesewitz and others 2006; Groffman and others 2006). This method does not measure actual denitrification rates since acetylene inhibits nitrification; however, it measures the activity of the resident denitrifier population under optimal conditions (total anoxia, constant mixing, unlimited nitrate and organic carbon) but without allowing new enzyme growth.

Assays were conducted in glass jars $(440 \mathrm{~mL}$ volume) with lids fitted with $n$-butyl rubber septa. Homogenised wet sediment samples $(60 \mathrm{~mL})$ were placed into jars with $54 \mathrm{~mL}$ unfiltered seawater 
Table 1. Sediment Properties and Macrofaunal Variables in Different Treatments

\begin{tabular}{|c|c|c|c|}
\hline Variable & Control $\left(0 \mathrm{~g} \mathrm{~N} \mathrm{~m}^{-2}\right)$ & Medium (150 $\left.\mathrm{g} \mathrm{N} \mathrm{m}^{-2}\right)$ & High $\left(600 \mathrm{~g} \mathrm{~N} \mathrm{~m}^{-2}\right)$ \\
\hline \multicolumn{4}{|l|}{ Sediment properties } \\
\hline Seagrass ( $\%$ cover $)$ & $16(0-84)$ & $20(0-97)$ & $21(0-75)$ \\
\hline $\mathrm{OC}(\%)$ & $0.9(0.6-2.0)$ & $0.9(0.6-2.0)$ & $1.0(0.6-1.8)$ \\
\hline Mud $(\%<63 \mu \mathrm{m})$ & $1.78(0-15)$ & $0.62(0-14)$ & $0.42(0-12)$ \\
\hline GSM $(\mu \mathrm{m})$ & $215(177-241)$ & $220(182-242)$ & $219(190-250)$ \\
\hline \multicolumn{4}{|c|}{ Microphytobenthic biomass ( $\mu \mathrm{g}^{-1}$ sediment) } \\
\hline Chl $a$ & $9.3(3-23)$ & $10.0(5-32)$ & $9.5(5-28)$ \\
\hline Phaeophytin & $4.4(1.5-18)$ & $6.4(1.6-22)$ & $4.0(1.1-19)$ \\
\hline \multicolumn{4}{|l|}{ Pore water $\mathrm{NH}_{4}^{+}(\mu \mathrm{M})$} \\
\hline Surface sediments $(0-2 \mathrm{~cm})$ & $24(0-198)$ & $253(0-2210)$ & $1849(111-10,239)$ \\
\hline Deeper sediments $(5-7 \mathrm{~cm})$ & $74(15-484)$ & $1209(99-10,275)$ & $5846(565-18,842)$ \\
\hline \multicolumn{4}{|l|}{ Macrofauna (n core $^{-1}$ ) } \\
\hline$S($ taxa $)$ & $10(6-16)$ & $10(4-15)$ & $8(3-16)$ \\
\hline$N$ (individuals) & $60(15-376)$ & $39(12-519)$ & $32(7-301)$ \\
\hline A. stutchburyi $(<10 \mathrm{~mm})$ & $6(0-91)$ & $2(0-99)$ & $2(0-64)$ \\
\hline A. stutchburyi ( $\geq 10 \mathrm{~mm})$ & $1(0-22)$ & $1(0-14)$ & $1(0-21)$ \\
\hline M. liliana $(<10 \mathrm{~mm})$ & $5(1-25)$ & $4(0-14)$ & $2(0-9)$ \\
\hline M. liliana ( $\geq 10 \mathrm{~mm})$ & $2(0-4)$ & $1(0-3)$ & $1(0-6)$ \\
\hline
\end{tabular}

Values are medians with minimum and maximum in parentheses $(n=28)$.

$O C=$ sediment organic content $; \mathrm{Mud}=$ sediment mud content; $G S M=$ grain size median; Chl a = chlorophyll a content; $S=$ number functional group species; $N=$ number of functional group individuals.

from the site. Chloramphenicol was added to prevent new enzyme synthesis at a final concentration of $0.06 \mathrm{~g} \mathrm{~L}^{-1}$. Assays were amended with unlimited carbon (30 $\mathrm{mg} \mathrm{L}^{-1} \mathrm{C}$ as glucose) and nitrate ( $10 \mathrm{mg} \mathrm{L}^{-1} \mathrm{~N}$ as $\mathrm{KNO}_{3}$ ). Anaerobic conditions were obtained by sealing the jars, evacuating with a vacuum pump for $4 \mathrm{~min}$, then purging with pure $\mathrm{N}_{2}$ gas for $10 \mathrm{~min}$. Pure acetylene was added as $10 \%$ of the headspace volume to prevent the conversion of $\mathrm{N}_{2} \mathrm{O}$ to $\mathrm{N}_{2}$. Assay jars were placed on shakers at $125 \mathrm{rpm}$ and incubated at $20^{\circ} \mathrm{C}$ for $2 \mathrm{~h}$. Headspace gas samples $(6 \mathrm{~mL})$ were collected at 10 , 30,60 and $120 \mathrm{~min}$ after the addition of acetylene. Gas samples were analysed using a Varian CP 3800 gas chromatograph equipped with a HayeSep D column and an electron capture detector.

Sediment dry weight (DW) in each assay jar was determined (after $48 \mathrm{~h}$ at $60^{\circ} \mathrm{C}$ ) and $\mathrm{N}_{2} \mathrm{O}$ produc-

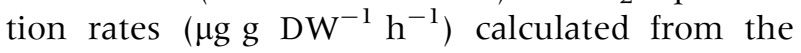
linear increase in concentration over time $\left(r^{2}>0.8\right)$. DEA was expressed per unit area of sandflat $\left(\mu \mathrm{mol} \mathrm{N} \mathrm{m} \mathrm{N}^{-2} \mathrm{~h}^{-1}\right)$ by multiplying the production rate by the sediment density ( $\mathrm{g}$ DW $\mathrm{cm}^{-3}$, determined by drying a known volume of the assay sediment) and sample depth $(5 \mathrm{~cm})$. Our analysis had a minimum DEA detection limit of $1 \mu \mathrm{mol} \mathrm{N} \mathrm{m} \mathrm{N}^{-2} \mathrm{~h}^{-1}$ and in preliminary testing replicate subsamples $(n=5)$ from homogenised sediment had a coefficient of variation (mean/SD) of $7 \%$, whereas the coefficient of variation between five replicate $1 \mathrm{~m}^{2}$ plots in a $25 \mathrm{~m}^{2}$ area at five sites was between 10 and 15\%.

Environmental variables were characterised as follows. Seagrass (Zostera muelleri Irmisch ex. Asch.) coverage $(\%)$ was estimated using photographs (taken before sampling) of the central $0.25 \mathrm{~m}^{2}$ of each plot and a random point count method (see Kohler and Gill 2006). Sediment cores from each plot were collected for analysis of pore water $\mathrm{NH}_{4}{ }^{+}$ ( $n=4,2.6 \mathrm{~cm}$ dia., $0-2$ and 5-7 cm depths, separated and depth sections pooled), sediment organic content, mud content $(\%<63 \mu \mathrm{m})$, grain size median, chlorophyll $a$, phaeophytin $(n=5,2.6 \mathrm{~cm}$ dia., pooled, $0-2 \mathrm{~cm}$ depth) and macrofauna community composition $(n=2,13 \mathrm{~cm}$ dia. pooled, $15 \mathrm{~cm}$ depth). Laboratory protocols are described in detail elsewhere (Douglas and others 2016), but briefly pore water was extracted by centrifugation, filtered $(1.1 \mu \mathrm{m}$ Whatman GC glass fibre filter), frozen $\left(-20^{\circ} \mathrm{C}\right)$ and then analysed for $\mathrm{NH}_{4}{ }^{+}$concentration using a Lachat QuickChem 8000 Series FIA+ (Lohrer and others 2010), sediment grain size was analysed with a Malvern Mastersizer 2000 after removal of organic matter (Singer and others 1988), sediment organic content was determined by loss on ignition $\left(550^{\circ} \mathrm{C}, 4 \mathrm{~h}\right)$ (Parker 1983) and microphytobenthic biomass was determined by extraction of pigments from freeze dried sediment (90\% acetone) and measuring fluorescence using a Turner Designs 10-AU flourometer (Arar and Col- 
lins 1997). Macrofaunal cores were sieved (500 $\mu \mathrm{m}$ mesh), preserved (50\% iso-propyl alcohol) and stained (Rose Bengal), and then, all organisms were counted and identified (usually to species level).

\section{Statistical Analysis}

A permutational multivariate analysis of variance (PERMANOVA, using a Euclidean distance matrix) was used to test for significant treatment effects on environmental variables (seagrass cover, sediment properties and microphytobenthic biomass). Due to the experimental design (that is, the spatial scale and selection of sites to maximise macrofauna diversity), there was, as expected, high intersite variability in DEA, macrofauna and environmental variables (Figure 1; Table 1). To compensate this natural heterogeneity and reveal potential treatment effects, we normalised site specific treatment response parameters by the corresponding control plot values so effect size was relative to the site specific background level. Normalisation assumes control plot values are representative of a site, a justifiable assumption given the small interplot distances $(2 \mathrm{~m})$ and strong positive correlations between control and treatment plot sediment properties and primary producer biomass/coverage (Pearson's $r>0.75, P<0.001$; raw data in Online Appendix 5). Treatment response variables (DEA and macrofauna community measures) were also correlated (Online Appendix 1). Control normalised (CN) DEA and community values were tested for differences from control values (that is, $\mathrm{DEA}_{\mathrm{CN}} \neq 1$; one-sample $t$-tests) and between fertiliser addition treatments (medium vs. high; twosample $t$-tests) using Statistica 11 (StatSoft Inc 2012).

Distance-based Linear Models (DistLM) were used to identify significant individual predictors (marginal tests) and then the best combination of predictor variables (backwards elimination procedure) of $\mathrm{DEA}_{\mathrm{CN}}$ at different levels of nutrient enrichment. Predictor variables included environmental variables and univariate measures of macrofaunal community composition. We used the corrected Akaike information criterion $\left(\mathrm{AIC}_{\mathrm{c}}\right)$ which is the most appropriate selection criterion when the number of variables is large compared to the sample size (Burnham and Anderson 2002). Predictor variables were normalised (between -2 and 2) to enable comparison among variables with different units without altering the distribution. Where there was co-linearity among variables $(r>0.7)$, the variable explaining the lesser amount of variability was excluded from full models (Dormann and others 2013). Variance partitioning analysis (Borcard and others 1992; Anderson and Cribble 1998) was used to determine how much of the model variance was attributed to grouped predictor variables, sediment pore water $\mathrm{NH}_{4}{ }^{+}$concentration [surface $(0-2 \mathrm{~cm})$ and deep (5$7 \mathrm{~cm})$ ], environmental variables [seagrass cover, sediment organic content (OC), median grain size (GSM), sediment mud content $(\%<63 \mu \mathrm{m}$; mud), chlorophyll $a$ (chl $a$ ), phaeophytin, distance from shore] and macrofaunal community variables (see below). All multivariate analyses were conducted using PRIMER 7.0 with PERMANOVA+ add-on (Clarke and Gorley 2015) with untransformed data.

For measures of macrofaunal community composition, we just considered the 46 species identified by Greenfield and others (2016) with traits important for nutrient processing. On average this functional group comprised $52 \%$ of the taxa and $63 \%$ of the abundance, and preliminary analyses indicated that this group had greater effects on DEA than the macrofaunal community considered as a whole. We included in analyses the number of species $(S)$ and individuals $(N)$ belonging to this functional group, and the abundances of juvenile $(<10 \mathrm{~mm})$ and adult $(\geq 10 \mathrm{~mm})$ A. stutchburyi and M. liliana. Austrovenus stutchburyi and M. liliana were included as separate predictors as both species have been shown to strongly influence ecosystem functioning (that is, are key species) on New Zealand sandflats (Thrush and others 2006; Sandwell and others 2009; Jones and others 2011; Pratt and others 2013; Thrush and others 2014) and we separated adults and juveniles because impacts on ecosystem differ with size (Hewitt and others 1997; Norkko and others 2013).

\section{Results}

\section{Nutrient Enrichment Effect on DEA}

Nutrient treatment (150 and $600 \mathrm{~g} \mathrm{~N} \mathrm{~m}^{-2}$ ) significantly increased pore water $\mathrm{NH}_{4}^{+}$concentrations throughout the sediment profile (Douglas and others 2016), but had no significant effects on sediment properties, seagrass cover or microphytobenthic biomass (Table 1; all PERMANOVA pseudo- $F=0.77, P>0.5$, not shown). There was substantial variability in DEA values in all treatments across the study site, with control plot values ranging from 7.6 to $183.2 \mu \mathrm{mol} \mathrm{N} \mathrm{m}{ }^{-2} \mathrm{~h}^{-1}$ (Figure 1A). The site specific DEA response to enrichment $\left(\mathrm{DEA}_{\mathrm{CN}}\right)$ ranged from 0.12 to 2.0 in medium 

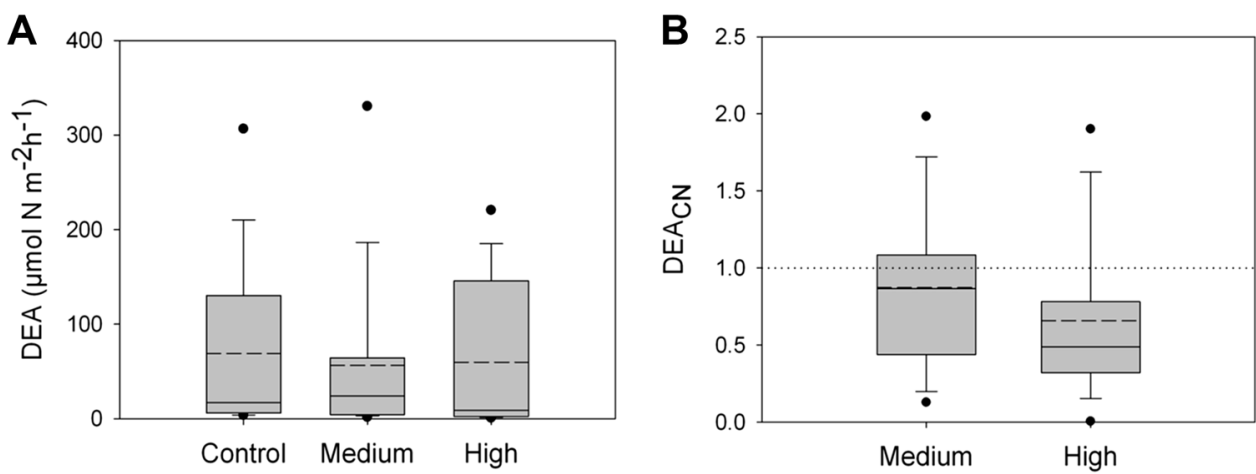

Figure 1. Effect of nutrient enrichment treatment on A DEA, and control normalised, B DEA $\left(\mathrm{DEA}_{\mathrm{CN}}\right), \mathbf{C}$ macrofaunal functional group diversity $\left(\mathrm{S}_{\mathrm{CN}}\right)$, D macrofaunal functional group abundance $\left(\mathrm{N}_{\mathrm{CN}}\right)$, E juvenile $(<10 \mathrm{~mm})$ and $\mathbf{F}$ adult $(\geq 10 \mathrm{~mm}) A$. stutchburyi $i_{\mathrm{CN}}$ abundance, and $\mathbf{G}$ juvenile
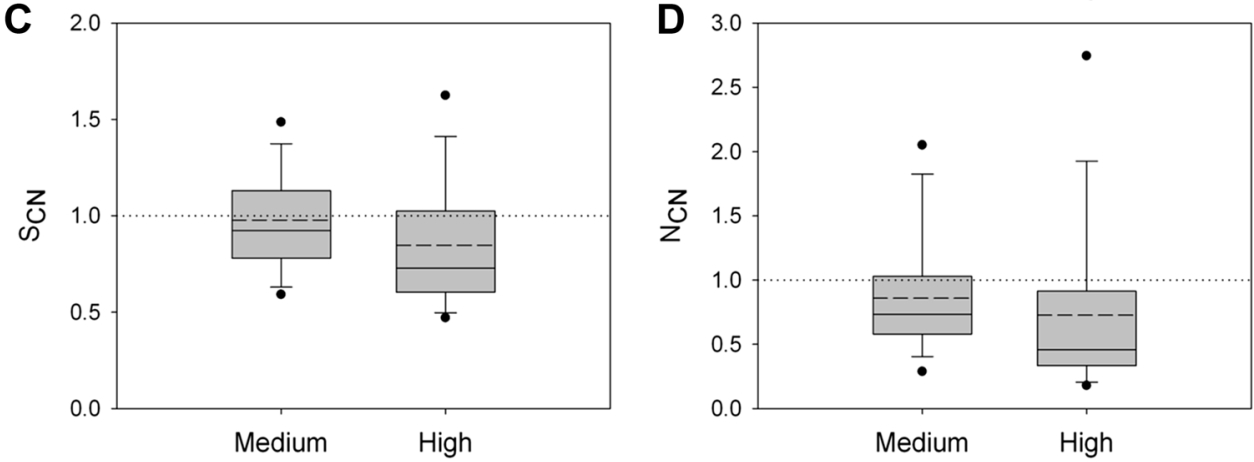

$(<10 \mathrm{~mm})$ and $\mathbf{H}$ adult $(\geq 10 \mathrm{~mm})$ M. liliana $_{\mathrm{CN}}$ abundance. Boxes are 25 th and 75 th percentiles, whiskers show 10th and 90th percentiles, black dots show 5th and 95th percentiles. Solid line is median, dashed line is mean, and in the normalised plots, the dotted line is provided for
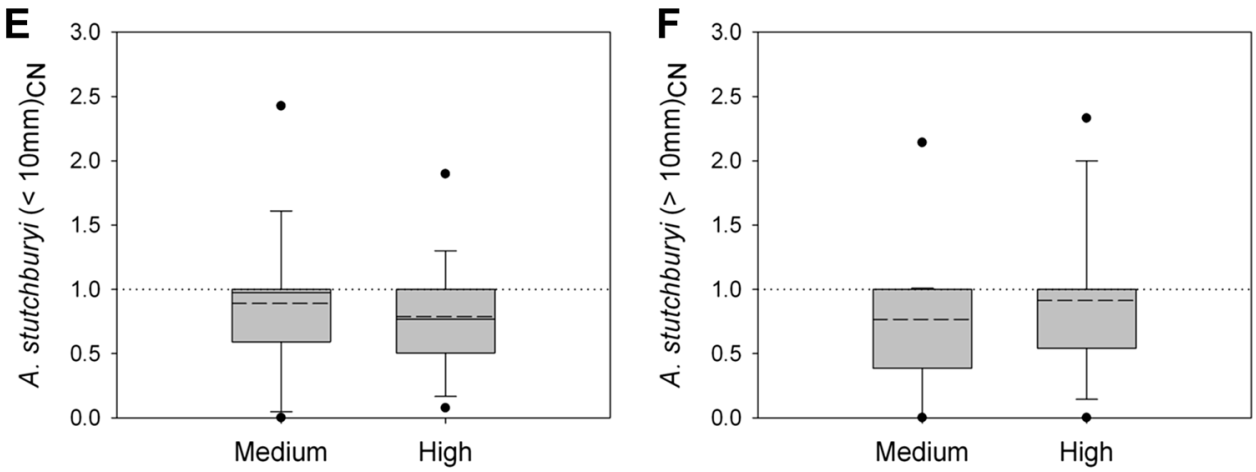
reference to the control value.
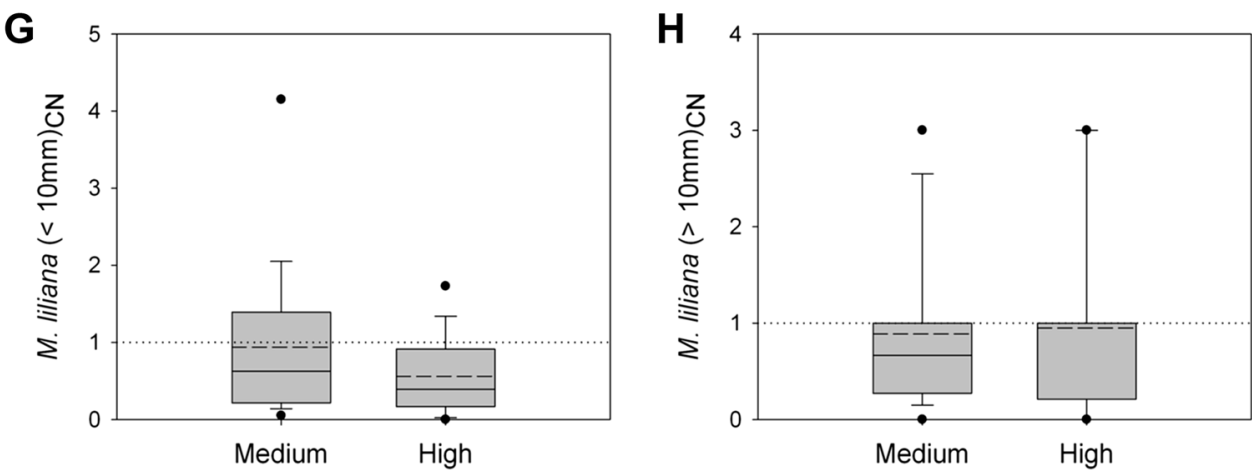

treatment plots (that is, $12-200 \%$ of control values), and 0.001 to 1.9 in high treatment plots (that is, 0.1 and $190 \%$ of control values). In the medium treatment 18 of 28 sites, and in the high treatment 21 of 28 sites, DEA values were less than in controls (that is, $\mathrm{DEA}_{\mathrm{CN}}<1$ ), indicating that DEA was, on average, suppressed by enrichment (Fig- ure 1B). In approximately $25 \%$ of treatment plots, enrichment enhanced DEA by greater than $20 \%$. Reductions in $\mathrm{DEA}_{\mathrm{CN}}$ were only significant in the high treatment; however, reductions were greater in the high compared with the medium treatment (although only marginally significant; Figure 1B; Table 2). 
Table 2. Treatment Effects on Control Normalised (CN) DEA and Macrofaunal Community Measures

\begin{tabular}{|c|c|c|c|c|c|}
\hline \multicolumn{2}{|l|}{ Treatment } & \multicolumn{2}{|c|}{ Difference from control } & \multicolumn{2}{|c|}{$\begin{array}{l}\text { Difference between treat- } \\
\text { ment means }\end{array}$} \\
\hline Variable & Mean & $t$ & $P$ & $t$ & $P$ \\
\hline \multicolumn{6}{|l|}{$\mathrm{DEA}_{\mathrm{CN}}$} \\
\hline Medium & 0.87 & -0.13 & 0.20 & \multirow[t]{2}{*}{1.86} & \multirow[t]{2}{*}{0.07} \\
\hline High & 0.66 & -3.41 & 0.002 & & \\
\hline \multicolumn{6}{|l|}{$\mathrm{S}_{\mathrm{CN}}$} \\
\hline Medium & 0.98 & -0.45 & 0.66 & \multirow[t]{2}{*}{2.85} & \multirow[t]{2}{*}{0.008} \\
\hline High & 0.85 & -2.50 & 0.02 & & \\
\hline \multicolumn{6}{|l|}{$\mathrm{N}_{\mathrm{CN}}$} \\
\hline Medium & 0.86 & -1.60 & 0.12 & \multirow[t]{2}{*}{1.44} & \multirow[t]{2}{*}{0.16} \\
\hline High & 0.73 & -2.05 & 0.05 & & \\
\hline \multicolumn{6}{|c|}{ A. stutchburyi $(<10 \mathrm{~mm})_{\mathrm{CN}}$} \\
\hline Medium & 0.89 & -1.01 & 0.32 & \multirow[t]{2}{*}{1.26} & \multirow[t]{2}{*}{0.22} \\
\hline High & 0.79 & -2.54 & 0.02 & & \\
\hline \multicolumn{6}{|c|}{ A. stutchburyi $(\geq 10 \mathrm{~mm})_{\mathrm{CN}}$} \\
\hline Medium & 0.77 & -2.13 & 0.04 & \multirow[t]{2}{*}{-0.92} & \multirow[t]{2}{*}{0.37} \\
\hline High & 0.91 & -0.77 & 0.45 & & \\
\hline \multicolumn{6}{|c|}{ M. liliana $(<10 \mathrm{~mm})_{\mathrm{CN}}$} \\
\hline Medium & 0.94 & -0.30 & 0.76 & \multirow[t]{2}{*}{1.94} & \multirow[t]{2}{*}{0.06} \\
\hline High & 0.56 & -4.54 & 0.0001 & & \\
\hline \multicolumn{6}{|c|}{ M. liliana $(\geq 10 \mathrm{~mm})_{\mathrm{CN}}$} \\
\hline Medium & 0.89 & -0.72 & 0.48 & \multirow[t]{2}{*}{-0.26} & \multirow[t]{2}{*}{0.80} \\
\hline High & 0.95 & -0.30 & 0.77 & & \\
\hline
\end{tabular}

\section{Predictors of DEA}

DEA was significantly correlated with a number of environmental variables (Online Appendices 2, 3, 4). In general, sites with higher control plot DEA were those with more sediment OC and mud, smaller median grain size, more seagrass coverage and more phaeophytin biomass. Control plot DEA was significantly correlated with DEA in both treatment plots (Online Appendix 1); that is, sites with naturally high DEA were also high following enrichment. Normalisation of medium and high treatment DEA by control values effectively removes spatial environmental influences, and consequently, these variables (and control plot DEA) did not explain a substantial proportion of $\mathrm{DEA}_{\mathrm{CN}}$ (Table 3, Online Appendices 3, 4). The predictors included in the full models of $\mathrm{DEA}_{\mathrm{CN}}$ differed depending on the level of enrichment (Table 3; Figure 2). In the medium treatment, surface sediment pore water $\mathrm{NH}_{4}{ }^{+}$concentration had a positive effect on $\mathrm{DEA}_{\mathrm{CN}}$, but community variables explained more of the response. Key bioturbators showed a strong influence on medium treatment
$\mathrm{DEA}_{\mathrm{CN}}$; together, juvenile and adult $M$. liliana and adult $A$. stutchburyi made up $32 \%$ of the total $54 \%$ explained variance. The effects of these two species on DEA $_{\mathrm{CN}}$ were different, $M$. liliana positive and $A$. stutchburyi negative (Table 3 ). Unlike the medium treatment, pore water $\mathrm{NH}_{4}^{+}$concentration was not an important predictor of $\mathrm{DEA}_{\mathrm{CN}}$ in the high treatment; only community variables were included in the full model explaining $39 \%$ of the variance, and key species did not have a significant role (Table 3; Figure 2B). Most (37\%) of the explained variance was attributed to the abundance of nutrient processing species $(N)$ which was positively correlated with $\mathrm{DEA}_{\mathrm{CN}}$. The amount of unexplained variance in $D_{E A} A_{C N}$ increased with the level of nutrient enrichment from 46 to $61 \%$.

\section{Nutrient Enrichment Effect on the Macrofaunal Community}

Analysis of control normalised measures of the nutrient processing functional group composition revealed significant treatment effects (Table 2; Figure $1 \mathrm{C}-\mathrm{H})$. The number of species $\left(S_{\mathrm{CN}}\right)$ was 
Table 3. DistLM Results for Treatment Plot Control Normalised DEA (DEA $\left.{ }_{\mathrm{CN}}\right)$

\begin{tabular}{|c|c|c|c|c|c|}
\hline Treatment & Group & Variable & Pseudo- $F$ & Prop. & Full model (\%) \\
\hline \multirow[t]{5}{*}{ Medium } & Pore water & $\mathrm{NH}_{4}^{+}(0-2 \mathrm{~cm})$ & 7.16 & $0.21^{* *}(+)$ & 19 \\
\hline & \multirow[t]{4}{*}{ Community } & M. liliana $(<10 \mathrm{~mm})$ & 5.19 & $0.16^{* *}(+)$ & 32 \\
\hline & & M. liliana ( $\geq 10 \mathrm{~mm})$ & 2.56 & 0.09 n.s. $(+)$ & \\
\hline & & A. stutchburyi ( $\geq 10 \mathrm{~mm})$ & 3.09 & $0.11 *(-)$ & \\
\hline & & & & Total & 54 \\
\hline \multirow[t]{6}{*}{ High } & \multirow[t]{2}{*}{ Environment } & Mud & 3.68 & $0.12 * *(+)$ & - \\
\hline & & Phaeophytin & 2.81 & $0.10 *(+)$ & - \\
\hline & \multirow[t]{4}{*}{ Community } & $S$ & 5.98 & $0.19 * * *(+)$ & - \\
\hline & & $N$ & 10.98 & $0.30 * *(+)$ & 37 \\
\hline & & M. liliana ( $\geq 10 \mathrm{~mm})$ & 0.50 & 0.02 n.s. $(-)$ & 9 \\
\hline & & & & Total & 39 \\
\hline
\end{tabular}

Prop. is the proportion of variability in DEA $A_{C N}$ explained by each variable when considered individually. Full model shows the variables included in the best DistLM of DEA $A_{C N}$ and the variance attributed to each.

$\mathrm{NH}_{4}^{+}(0-2 \mathrm{~cm})=$ surface sediment pore water ammonium concentration $(\mu \mathrm{M}) ; \mathrm{Mud}=$ sediment mud content $(\%) ;$ phaeophytin $\left(\mu \mathrm{g} \mathrm{g}^{-1}\right.$ sediment); $S=$ number functional group species; $N=$ number of functional group individuals

Significance levels are ${ }^{*} P \leq 0.1,{ }^{*} P \leq 0.05, * * * P \leq 0.01$, and correlation directions are in parentheses.
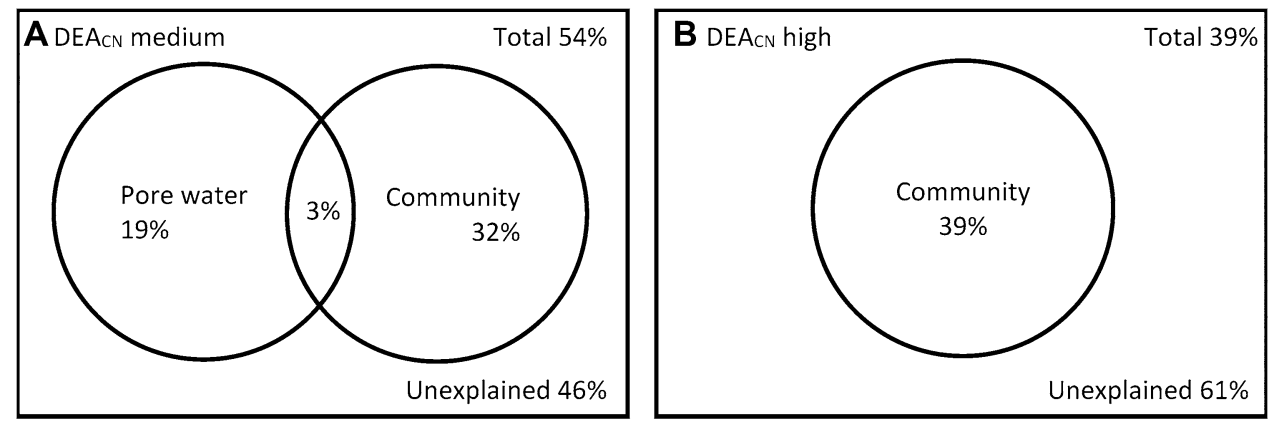

Figure 2. Diagrams presenting partitioning of variance in $\mathrm{DEA}_{\mathrm{CN}}$ in $\mathbf{A}$ medium and $\mathbf{B}$ high treatment attributed to unique and shared effects of measures of community and pore water ammonium concentration (realised treatment effect). Results from variance partitioning analysis of full DistLM as described in Table 3.

lower in the high than control and medium treatments, and there were reductions in the total abundance $\left(N_{\mathrm{CN}}\right)$, but this was only significant in the high treatment. The abundance of key bioturbating species were also negatively impacted with nutrient enrichment. Adult and juvenile A. stutchburyi densities were reduced in the medium and high treatments, respectively. For M. liliana, only juveniles (which were numerically dominant) were affected, only in the high treatment (Table 2).

\section{Discussion}

We examined the role of macrofauna diversity in moderating nutrient oversupply using an indirect measure of nutrient processing capacity (DEA) across 28 sites with substantial natural variability in the community composition of nutrient processors. DEA was spatially highly variable which was ex- pected given the heterogeneity of the sandflat and sites with naturally high DEA were also high following nutrient enrichment. By normalising treatment plot DEA by control values, we revealed the response to nutrient addition and demonstrate in a real-world setting that benthic macrofaunal diversity is important to the preservation of denitrification $\left(D_{\mathrm{N}}\right)$ following nutrient stress. This is significant because $D_{\mathrm{N}}$ is a process that can mitigate eutrophication, and nutrient enrichment commonly has negative effects on benthic macrofauna (Pearson and Rosenberg 1978).

Fertiliser addition on average suppressed DEA (that is, $\mathrm{DEA}_{\mathrm{CN}}<1$ ) especially in the high treatment, and we assume this suppression was due to inhibition of nitrification (although we did not measure this process directly). Most of the $D_{\mathrm{N}}$ in this system is likely to be coupled to nitrification because control plot DEA strongly correlates with 
sediment organic content (suggesting organic matter mineralisation is the primary source of $N$; Online Appendix 2) (Sloth and others 1995; Seitzinger and others 2006), and New Zealand estuaries typically have low pore water and water column nitrate concentrations (Lohrer and others 2004; Thrush and others 2006; Lohrer and others 2010). Nitrification inhibition would occur if the enriched sediments became periodically anoxic or the oxic layer depth decreased (preventing or reducing nitrification of $\mathrm{NH}_{4}{ }^{+}$even when present in great quantity) (Joye and Hollibaugh 1995; Magalhães and others 2005; Foster and Fulweiler 2014). Shifts towards anaerobic conditions may have been caused by the $\mathrm{NH}_{4}{ }^{+}$-induced reduction in the abundance of bioturbating species (Table 2; Figure $1 \mathrm{C}-\mathrm{H}$ ) which would reduce oxygenation of the sediments (Diaz and Rosenberg 1995, 2008; Glud 2008) and further exacerbated by dead macrofauna stimulating microbial metabolism during decay (Kelly and Nixon 1984; Blackburn and others 1993). But note there was no detectable enrichment of sediment organic content in treatment plots that could be related to macrofauna mortality (Table 1).

Although enrichment suppressed DEA $\mathrm{CN}_{\mathrm{C}}$ at most sites, the response represented a continuum from inhibition to enhancement. DistLM showed that $39-54 \%$ of response to enrichment could be explained, most of it by macrofaunal diversity. It is difficult to speculate on the source(s) of the unexplained variation in $\mathrm{DEA}_{\mathrm{CN}}$, but on a dynamic intertidal sandflat spatial and temporal variations in sediment biogeochemistry caused by hydrodynamic forcing (Green and Coco 2014; Huettel and others 2014), foraging and excretion by large predators (for example, Thrush and others 1994; Hines and others 1997; Jauffrais and others 2015), detrital inputs (for example, Eyre and Ferguson 2002; Eyre and others 2013) and microbial diversity (for example, Yazdani Foshtomi and others 2015) could all contribute, as could any initial small-scale variation between plots within a site. Nevertheless, the fact that a substantial proportion of the DEA response could be explained by macrofauna diversity despite the complexity of the field setting emphasises its importance in regulating the effects of enrichment.

When $\mathrm{NH}_{4}{ }^{+}$was supplied in the medium treatment, the density of $M$. liliana was critical in mediating the response of DEA. Both the concentration of surface sediment pore water $\mathrm{NH}_{4}{ }^{+}$and abundances of $M$. liliana were significantly positively correlated with $\mathrm{DEA}_{\mathrm{CN}}$. This agrees with our expectation that factors that promote the coupling of nitrification and $D_{\mathrm{N}}$ (that is, bioturbation-induced increases in sediment oxygenation and solute transport) would lessen the negative effect of enrichment on DEA (that is, $\mathrm{DEA}_{\mathrm{CN}}$ declines from 1 would be less). Macomona liliana is a surface deposit feeding bivalve known to influence sedimentary oxygen and nitrogen fluxes (Thrush and others 2006; Volkenborn and others 2012; Pratt and others 2015). The feeding and burrowing behaviour of this species injects pulses of oxygen-rich water into sediments as well as creating hydrostatic pressure gradients in the sediment profile. This increases the oxic-anoxic interface (both spatially and temporally), accelerates solute exchange and forces nutrient-rich anoxic water shallower in the sediment profile (and into the oxic nitrification zone) (Volkenborn and others 2012). Others have shown that under well-flushed conditions (that is, via bioturbation and/or in permeable sediments advective pore water flushing) nitrification is positively correlated with $\mathrm{NH}_{4}{ }^{+}$concentrations (Caffrey and others 2003; Huettel and others 2014); in this case, bioturbation by M. liliana appears to be the flushing mechanism.

Adult M. liliana $(\geq 10 \mathrm{~mm})$ live deep in the anoxic zone of the sediments (about $10 \mathrm{~cm}$ depth) (Hewitt and others 1997) and therefore are likely to have a strong positive influence on coupled $D_{\mathrm{N}}$. In our study, adult $M$. liliana did not show significant individual effects on $\mathrm{DEA}_{\mathrm{CN}}$; this is unsurprising given that they were in low densities, and sampling two $0.13 \mathrm{~m}^{2}$ area cores per plot unlikely gives an accurate representation of the resident individuals. Despite this, adult $M$. liliana still featured in models explaining variance in $\mathrm{DEA}_{\mathrm{CN}}$ in both treatments, suggesting an influence on the activity of the resident denitrifier population. Our grouping of juvenile $M$. liliana included all those less than $10 \mathrm{~mm}$, encompassing young juveniles $(\leq 5 \mathrm{~mm})$ that occupy surface sediments $(<2 \mathrm{~cm}$ depth, within typical oxic zones) and larger juveniles $(5-10 \mathrm{~mm}$ ) that occupy sediments between 2 and $10 \mathrm{~cm}$ depth (Hewitt and others 1997), below the typical oxic depth of these types of sediments. Juveniles $(<10 \mathrm{~mm})$ showed a strong positive effect on medium treatment $\mathrm{DEA}_{\mathrm{CN}}$ and despite being shallower dwelling than adults, their activities are likely to increase oxic zones and the transport of nutrient-rich pore water (relative to un-bioturbated sediments) also facilitating coupled $D_{\mathrm{N}}$.

Negative ecosystem effects increased with increased nutrient enrichment (that is, from medium to high); in particular loss of key species and decreases in DEA performance. The high nutrient treatment reduced the abundance of juvenile $M$. 
liliana and subsequently the positive influence on $\mathrm{DEA}_{\mathrm{CN}}$ seen in the medium treatment was gone. With reduced abundance of this key species under high nutrient stress, the fundamental role in explaining $\mathrm{DEA}_{\mathrm{CN}}$ (and supporting coupled $D_{\mathrm{N}}$ ) was taken up by the remaining community of nutrient processing macrofauna. Both the diversity $(S)$ and abundance $(N)$ of the functional group were significantly positively correlated with $\mathrm{DEA}_{\mathrm{CN}}$, indicating that both are important for maintaining coupled $D_{\mathrm{N}}$ (and therefore nitrogen removal) under high nutrient stress (albeit at reduced efficiency). It is possible that pore water $\mathrm{NH}_{4}{ }^{+}$concentrations, particularly in high treatments, reached a threshold where nitrification was either saturated or suppressed (Anthonisen and others 1976; Henriksen and Kemp 1988). Maintenance of nutrient processing from bioturbation is important for resistance to negative feedbacks that cause nitrification inhibition. Our study has shown that different elements of biodiversity, especially functional group species abundance and diversity, and key species size and abundance, are important for ecosystem functioning under increasing nutrient stress. Nutrient stress caused reduced diversity of nutrient processors which may lead to reductions in ecosystem resilience to nutrient enrichment. Such effects may be further exacerbated by multiple stressor effects associated with habitat loss, pollution and fisheries exploitation (Rothschild and others 1994; Thrush and Dayton 2002; Lohrer and others 2004; Solan and others 2004).

Land-use intensification and terrestrial nutrient loading to the marine environment will continue to increase therefore maintenance of soft sediment nutrient processing will be paramount for coastal ecosystem resilience to eutrophication. This in situ study has demonstrated that under nutrient stressed conditions, key species, and then functional group abundance and diversity govern an essential nitrogen removal process that may ultimately mitigate shifts towards eutrophication. Furthermore, our results provide an example of how community response diversity contributes to ecosystem resilience to nutrient enrichment stress (Elmqvist and others 2003; Mori and others 2013). Increasing stress to soft sediment ecosystems can cause loss of bioturbators, decoupling of processes and changes in ecosystem functioning (Lohrer and others 2011; Pratt and others 2013). This is a concern for sediment nitrogen removal given the demonstrated dependence of soft sediment ecosystem processes on macrobenthic communities. Although both the medium and high levels of nutrient stress led to reductions in nutrient pro- cessing, the effects were greater with the higher level of stress, due to the reduced abundance of a key species and decoupling of processes that occurred in this treatment type. This supports the notion that losses of large or functional species that play pivotal roles in ecosystem processes leads to loss of ecosystem resilience (Thrush and others 2006; Norkko and others 2013), with implications for future management of coastal ecosystems. If stress thresholds are crossed, causing reductions in key nutrient processing species and functional diversity, there may be long-term effects on ecosystem resilience to eutrophication. This could contribute to tipping points and major regime shifts in coastal ecosystems (Thrush and others 2014).

\section{ACKNOWLEDGEMENTS}

We thank all those involved in field sampling and laboratory work, especially Barry Greenfield, Sarah Hailes, Lisa McCartain, Katie Cartner, Kelly Carter, Rosalie Carter, Carsten Dormann, Chris Eager, Laura Hines and Rebecca Gladstone-Gallagher. Special thanks to Judi Hewitt for advice with statistical analysis and two anonymous reviewers whose constructive comments improved the manuscript. This work was funded by the Marsden Fund, Royal Society of New Zealand (NIW1102) to SFT, a Marie-Curie International Outgoing Fellowship (FP7-PEOPLE-2011-IOF) to CK and CO1x1515 4.2.1 to SFT and CAP. EJD was funded by a University of Waikato Doctoral Scholarship. These funders had no role in the study design, interpretation or writing of this manuscript.

\section{Compliance with Ethical Standards}

Conflict of interest The authors declare that they have no conflict of interest.

\section{REFERENCES}

Anderson MJ, Cribble NA. 1998. Partitioning the variation among spatial, temporal and environmental components in a multivariate data set. Australian Journal of Ecology 23:15867.

Anthonisen AC, Loehr RC, Prakasam TBS, Srinath EG. 1976. Inhibition of nitrification by ammonia and nitrous acid. Water Pollution Control Federation 48:835-52.

Arar E, Collins G. 1997. In vitro determination of chlorophyll a and pheophytin a in marine and freshwater algae by fluorescence. Cincinnati: National Exposure Research Laboratory, U.S. Environmental Protection Agency.

Barnes J, Owens NJP. 1998. Denitrification and nitrous oxide concentrations in the Humber estuary, UK, and adjacent coastal zones. Marine Pollution Bulletin 37:247-60. 
Bernot MJ, Dodds WK, Gardner WS, McCarthy MJ, Sobolev D, Tank JL. 2003. Comparing denitrification estimates for a Texas estuary by using acetylene inhibition and membrane inlet mass spectrometry. Applied and Environmental Microbiology 69:5950-6.

Blackburn TH, Blackburn ND, Mortimer RJG, Coleman ML, Lovley DR. 1993. Rates of microbial processes in sediments. Philosophical Transactions: Physical Sciences and Engineering 344:49-58 (and discussion).

Borcard D, Legendre P, Drapeau P. 1992. Partialling out the spatial component of ecological variation. Ecology 73:104555.

Bruesewitz DA, Hamilton DP, Schipper LA. 2011 . Denitrification potential in lake sediment increases across a gradient of catchment agriculture. Ecosystems 14:341-52.

Bruesewitz DA, Tank JL, Bernot MJ, Richardson WB, Strauss EA. 2006. Seasonal effects of the zebra mussel (Dreissena polymorpha) on sediment denitrification rates in Pool 8 of the Upper Mississippi River. Canadian Journal of Fisheries and Aquatic Sciences 63:957-69.

Burnham KP, Anderson DR. 2002. Model selection and multimodel inference: a pratical information-theoretic approach. New York (NY): Springer.

Caffrey JM, Harrington N, Solem I, Ward BB. 2003. Biogeochemical processes in a small California estuary. 2. Nitrification activity, community structure and role in nitrogen budgets. Marine Ecology Progress Series 248:27-40.

Chapin FS, Zavaleta ES, Eviner VT, Naylor RL, Vitousek PM, Reynolds HL, Hooper DU, Lavorel S, Sala OE, Hobbie SE, Mack MC, Diaz S. 2000. Consequences of changing biodiversity. Nature 405:234-42.

Clarke KR, Gorley RN. 2015. PRIMER v7: User manual/tutorial. Plymouth, 296 pp: PRIMER-E.

de Juan S, Thrush SF, Hewitt JE, Halliday J, Lohrer AM. 2014. Cumulative degradation in estuaries: contribution of individual species to community recovery. Marine Ecology Progress Series 510:25-38

Diaz RJ, Rosenberg R. 1995. Marine benthic hypoxia: a review of its ecological effects and the behavioural responses of benthic macrofauna. In: Ansell AD, Gibson RN, Barnes M, Eds. Oceanography and marine biology-an annual review, Vol. 33. London: UCL Press Ltd. p 245-303.

Diaz RJ, Rosenberg R. 2008. Spreading dead zones and consequences for marine ecosystems. Science 321:926-9.

Doak DF, Bigger D, Harding EK, Marvier MA, O'Malley RE, Thomson D. 1998. The statistical inevitability of stability-diversity relationships in community ecology. American Naturalist 151:264-76.

Dormann CF, Elith J, Bacher S, Buchmann C, Carl G, Carré G, Marquéz JRG, Gruber B, Lafourcade B, Leitão PJ, Münkemüller T, McClean C, Osborne PE, Reineking B, Schröder B, Skidmore AK, Zurell D, Lautenbach S. 2013. Collinearity: a review of methods to deal with it and a simulation study evaluating their performance. Ecography 36:27-46.

Douglas EJ, Pilditch CA, Hines LV, Kraan C, Thrush SF. 2016. In situ soft sediment nutrient enrichment: a unified approach to eutrophication field experiments. Marine Pollution Bulletin $111: 287-94$.

Elmqvist T, Folke C, Nyström M, Peterson G, Bengtsson J, Walker B, Norberg J. 2003. Response diversity, ecosystem change, and resilience. Frontiers in Ecology and the Environment 1:488-94.
Eyre BD, Ferguson AJP. 2002. Comparison of carbon production and decomposition, benthic nutrient fluxes and denitrification in seagrass, phytoplankton, benthic microalgae- and macroalgae-dominated warm-temperate Australian lagoons. Marine Ecology Progress Series 229:43-59.

Eyre BD, Maher DT, Squire P. 2013. Quantity and quality of organic matter (detritus) drives $\mathrm{N}_{2}$ effluxes (net denitrification) across seasons, benthic habitats and estuaries. Global Biogeochemical Cycles 27:1083-95.

Fitch JE, Crowe TP. 2012. Combined effects of inorganic nutrients and organic enrichment on intertidal benthic macrofauna: an experimental approach. Marine Ecology Progress Series 461:59-70.

Folke C, Carpenter S, Walker B, Scheffer M, Elmqvist T, Gunderson L, Holling CS. 2004. Regime shifts, resilience, and biodiversity in ecosystem management. Annual Review of Ecology, Evolution, and Systematics 35:557-81.

Foster SQ, Fulweiler RW. 2014. Spatial and historical variability of benthic nitrogen cycling in an anthropogenically impacted estuary. Frontiers in Marine Science 1:56.

Galloway JN, Aber JD, Erisman JW, Seitzinger SP, Howarth RW Cowling EB, Cosby BJ. 2003. The nitrogen cascade. Bioscience 53:341-56

Galloway JN, Townsend AR, Erisman JW, Bekunda M, Cai ZC, Freney JR, Martinelli LA, Seitzinger SP, Sutton MA. 2008. Transformation of the nitrogen cycle: recent trends, questions, and potential solutions. Science 320:889-92.

Gilbert F, Stora G, Bonin P. 1998. Influence of bioturbation on denitrification activity in Mediterranean coastal sediments: an in situ experimental approach. Marine Ecology Progress Series 163:99-107.

Gladstone-Gallagher RV, Lundquist CJ, Pilditch CA. 2014. Response of temperate intertidal benthic assemblages to mangrove detrital inputs. Journal of Experimental Marine Biology and Ecology 460:80-8.

Gladstone-Gallagher RV, Lohrer AM, Lundquist CJ, Pilditch CA. 2016. Effects of detrital subsidies on soft-sediment ecosystem function are transient and source-dependent. PLoS ONE $11: \mathrm{e} 0154790$

Glud RN. 2008. Oxygen dynamics of marine sediments. Marine Biology Research 4:243-89.

Gray JS, Wu RSS, Ying YO. 2002. Effects of hypoxia and organic enrichment on the coastal marine environment. Marine Ecology Progress Series 238:249-79.

Green MO, Coco G. 2014. Review of wave-driven sediment resuspension and transport in estuaries. Reviews of Geophysics 52:77-117.

Greenfield BL, Kraan C, Pilditch CA, Thrush SF. 2016. Mapping functional groups can provide insight into ecosystem functioning and potential resilience of intertidal sandflats. Marine Ecology Progress Series 548:1-10.

Groffman PM, Altabet MA, Böhlke JK, Butterbach-Bahl K, David MB, Firestone MK, Giblin AE, Kana TM, Nielsen LP, Voytek MA. 2006. Methods for measuring denitrification: diverse approaches to a difficult problem. Ecological Applications 16:2091-122.

Groffman PM, Holland EA, Myrold DD, Robertson GP. 1999. Denitrification. In: Robertson G, Bledsoe C, Coleman D, Sollins P, Eds. Standard soil methods for long term ecological research. Cary (NC): Oxford University Press. p 272-88.

Henriksen K, Kemp WM. 1988. Nitrification in estuarine and coastal marine sediments. In: Blackburn TH, Sorensen J, Eds. 
Nitrogen cycling in coastal marine environments. New York: Wiley. p 207-49.

Hewitt J, Thrush S, Lohrer A, Townsend M. 2010. A latent threat to biodiversity: consequences of small-scale heterogeneity loss. Biodiversity and Conservation 19:1315-23.

Hewitt JE, Legendre P, McArdle BH, Thrush SF, Bellehumeur C, Lawrie SM. 1997. Identifying relationships between adult and juvenile bivalves at different spatial scales. Journal of Experimental Marine Biology and Ecology 216:77-98.

Hewitt JE, Thrush SF. 2010. Empirical evidence of an approaching alternate state produced by intrinsic community dynamics, climatic variability and management actions. Marine Ecology Progress Series 413:267-76.

Hines AH, Whitlatch RB, Thrush SF, Hewitt JE, Cummings VJ, Dayton PK, Legendre P. 1997. Nonlinear foraging response of a large marine predator to benthic prey: eagle ray pits and bivalves in a New Zealand sandflat. Journal of Experimental marine Biology and Ecology 216:191-210.

Huettel M, Berg P, Kostka JE. 2014. Benthic exchange and biogeochemical cycling in permeable sediments. Annual Review of Marine Science 6:23-51.

Jones HFE, Pilditch CA, Bruesewitz DA, Lohrer AM. 2011. Sedimentary environment influences the effect of an infaunal suspension feeding bivalve on estuarine ecosystem function. PLOS ONE 6:e27065.

Jauffrais T, Drouet S, Turpin V, Mèlèder V, Jesus B, Cognie B, Raimbault $\mathrm{P}$, Cosson RP, Decottignies $\mathrm{P}$, Martin-Jèzèquel V. 2015. Growth and biochemical composition of a microphytobenthic diatom (Entomoneis paludosa) exposed to shorebird (Calidris alpina) droppings. Journal of Experimental Marine Biology and Ecology 469:83-92.

Joye SB, Hollibaugh JT. 1995. Influence of sulfide inhibition of nitrification on nitrogen regeneration in sediments. Science 270:623-5.

Kelly JR, Nixon S. 1984. Experimental studies of the effect of organic deposition on the metabolism of a coastal marine bottom community. Marine Ecology Progress Series 17:15769.

Kohler K, Gill S. 2006. Coral point count with Excel extensions (CPCe): a Visual Basic program for the determination of coral and substrate coverage using random point count methodology. Computers and Geosciences 32:1259-69.

Koop-Jakobsen K, Giblin AE. 2010. The effect of increased nitrate loading on nitrate reduction via denitrification and DNRA in salt marsh sediments. Limnology and Oceanography 55:789-802.

Kraan C, Dormann CF, Greenfield BL, Thrush SF. 2015. Crossscale variation in biodiversity-environment links illustrated by coastal sandflat communities. PLoS ONE 10:e0142411.

Kristensen E, Jensen MH, Aller RC. 1991. Direct measurement of dissolved inorganic nitrogen exchange and denitrification in individual polychaete (Nereis-virens) burrows. Journal of Marine Research 49:355-77.

Kristensen E, Jensen MH, Andersen TK. 1985. The impact of polychaete (Nereis virens Sars) burrows on nitrification and nitrate reduction in estuarine sediments. Journal of Experimental Marine Biology and Ecology 85:75-91.

Laursen AE, Seitzinger SP, Dekorsey R, Sanders JG, Breitburg DL, Osman RW. 2002. Multiple stressors in an estuarine system: effects of nutrients, trace elements, and trophic complexity on benthic photosynthesis and respiration. Estuaries 25:57-69.
Laverock B, Gilbert JA, Tait K, Osborn AM, Widdicombe S. 2011. Bioturbation: impact on the marine nitrogen cycle. Biochemical Society Transactions 39:315-20.

Livingstone MW, Smith RV, Laughlin RJ. 2000. A spatial study of denitrification potential of sediments in Belfast and Strangford Loughs and its significance. Science of the Total Environment 251:369-80.

Lohrer AM, Halliday NJ, Thrush SF, Hewitt JE, Rodil IF. 2010. Ecosystem functioning in a disturbance-recovery context: contribution of macrofauna to primary production and nutrient release on intertidal sandflats. Journal of Experimental Marine Biology and Ecology 390:6-13.

Lohrer AM, Hewitt JE, Hailes SF, Thrush SF, Ahrens M, Halliday J. 2011. Contamination on sandflats and the decoupling of linked ecological functions. Austral Ecology 36:378-88.

Lohrer AM, Thrush SF, Gibbs MM. 2004. Bioturbators enhance ecosystem function through complex biogeochemical interactions. Nature 431:1092-5.

Loreau M, Naeem S, Inchausti P, Bengtsson J, Grime JP, Hector A, Hooper DU, Huston MA, Raffaelli D, Schmid B, Tilman D, Wardle DA. 2001. Biodiversity and ecosystem functioning: current knowledge and future challenges. Science 294:804-8.

Magalhães CM, Joye SB, Moreira RM, Wiebe WJ, Bordalo AA. 2005. Effect of salinity and inorganic nitrogen concentrations on nitrification and denitrification rates in intertidal sediments and rocky biofilms of the Douro River estuary, Portugal. Water Research 39:1783-94.

Mori AS, Furukawa T, Sasaki T. 2013. Response diversity determines the resilience of ecosystems to environmental change. Biol Rev Camb Philos Soc 88:349-64.

Morris L, Keough MJ. 2003. Variation in the response of intertidal infaunal invertebrates to nutrient additions: field manipulations at two sites within Port Phillip Bay, Australia. Marine Ecology Progress Series 250:35-49.

Naeem S, Thompson LJ, Lawler SP, Lawton JH, Woodfin RM. 1994. Declining biodiversity can alter the performance of ecosystems. Nature 368:734-7.

Nixon S. 1998. Enriching the sea to death. Scientific American 9:48-53.

Nogaro G, Burgin AJ. 2014. Influence of bioturbation on denitrification and dissimilatory nitrate reduction to ammonium (DNRA) in freshwater sediments. Biogeochemistry 120:27994.

Norkko A, Villnas A, Norkko J, Valanko S, Pilditch C. 2013. Size matters: implications of the loss of large individuals for ecosystem function. Scientific Reports 3:2646.

Oakes JM, Eyre BD, Ross DJ. 2011. Short-term enhancement and long-term suppression of denitrification in estuarine sediments receiving primary- and secondary-treated paper and pulp mill discharge. Environmental Science and Technology 45:3400-6.

Parker JG. 1983. A comparison of methods used for the measurement of organic matter in marine sediment. Chemistry and Ecology 1:201-9.

Pearson TH, Rosenberg R. 1978. Macrobenthic succession in relation to organic enrichment and pollution of the marine environment. Oceanography and Marine Biology: An Annual Review 16:229-311.

Pelegri SP, Nielsen LP, Blackburn TH. 1994. Denitrification in estuarine sediment stimulated by the irrigation activity of the amphipod Corophium volutator. Marine Ecology Progress Series 105:285-90. 
Piehler MF, Smyth AR. 2011. Habitat-specific distinctions in estuarine denitrification affect both ecosystem function and services. Ecosphere 2:artl2.

Posey MH, Alphin TD, Cahoon L. 2006. Benthic community responses to nutrient enrichment and predator exclusion: influence of background nutrient concentrations and interactive effects. Journal of Experimental Marine Biology and Ecology 330:105-18.

Pratt DR, Lohrer AM, Pilditch CA, Thrush SF. 2013. Changes in ecosystem function across sedimentary gradients in estuaries. Ecosystems 17:182-94.

Pratt DR, Lohrer AM, Thrush SF, Hewitt JE, Townsend M, Cartner K, Pilditch CA, Harris RJ, van Colen C, Rodil IF. 2015. Detecting subtle shifts in ecosystem functioning in a dynamic estuarine environment. PLoS ONE 10:e0133914.

Rothschild BJ, Ault JS, Goulletquer P, Héral M. 1994. Decline of the Chesapeake Bay oyster population: a century of habitat destruction and overfishing. Marine Ecology Progress Series $111: 29-39$.

Sandwell DR, Pilditch CA, Lohrer AM. 2009. Density dependent effects of an infaunal suspension-feeding bivalve (Austrovenus stutchburyi) on sandflat nutrient fluxes and microphytobenthic productivity. Journal of Experimental Marine Biology and Ecology 373:16-25.

Seitzinger S, Harrison JA, Böhlke JK, Bouwman AF, Lowrance R, Peterson B, Tobias C, Van Drecht G. 2006. Denitrification across landscapes and waterscapes: a synthesis. Ecological Applications 16:2064-90.

Singer JK, Anderson JB, Ledbetter MT, McCave IN, Jones KPN, Wright R. 1988. An assessment of analytical techniques for the size analysis of fine-grained sediments. Journal of Sedimentary Research 58:534-43.

Sloth NP, Blackburn H, Hansen LS, Risgaard-Pedersen N, Lomstein BA. 1995. Nitrogen cycling in sediments with different organic loading. Marine Ecology Progress Series 116:163-70.

Solan M, Cardinale BJ, Downing AL, Engelhardt KAM, Ruesink JL, Srivastava DS. 2004. Extinction and ecosystem function in the marine benthos. Science 306:1177-80.

StatSoft Inc. 2012. STATISTICA (data analysis software system), version 11. www.statsoft.com.

Stief P. 2013. Stimulation of microbial nitrogen cycling in aquatic ecosystems by benthic macrofauna: mechanisms and environmental implications. Biogeosciences Discussions 10:11785-824.

Teixeira C, Magalhães C, Boaventura RAR, Bordalo AA. 2010. Potential rates and environmental controls of denitrification and nitrous oxide production in a temperate urbanized estuary. Marine Environmental Research 70:336-42.

Thrush S, Hewitt J, Parkes S, Lohrer A, Pilditch C, Woodin SA, Wethey D, Chiantore M, Asnaghi V, De Juan S, Kraan C, Rodil I, Savage C, Van Colen C. 2014. Experimenting with ecosystem interaction networks in search of threshold potentials in real world marine ecosystems. Ecology 95:1451-7.
Thrush SF, Coco G, Hewitt JE. 2008. Complex positive connections between functional groups are revealed by neural network analysis of ecological time series. American Naturalist 171:669-77.

Thrush SF, Dayton PK. 2002. Disturbance to marine benthic habitats by trawling and dredging: implications for marine biodiversity. Annual Review of Ecology and Systematics 33:449-73.

Thrush SF, Hewitt JE, Gibbs M, Lundquist C, Norkko A. 2006. Functional role of large organisms in intertidal communities: community effects and ecosystem function. Ecosystems 9:1029-40.

Thrush SF, Prridmore RD, Hewitt JE, Cummings VJ. 1994. The improtance of predators on a sandflat: interplay between seasonal change sin prey densities and predator effects. Marine Ecology Progress Series 107:211-22.

Tiedje JM, Simkins S, Groffman PM. 1989. Perspectives on measurement of denitrification in the field including recommended protocols for acetylene based methods. Plant and Soil 115:261-84.

Vieillard AM, Fulweiler RW. 2012. Impacts of long-term fertilization on salt marsh tidal creek benthic nutrient and $\mathrm{N}_{2}$ gas fluxes. Marine Ecology Progress Series 471:11-22.

Villnäs A, Norkko J, Hietanen S, Josefson AB, Lukkari K, Norkko A. 2013. The role of recurrent disturbances for ecosystem multifunctionality. Ecology 94:2275-87.

Vitousek PM, Aber JD, Howarth RW, Likens GE, Matson PA, Schindler DW, Schlesinger WH, Tilman D. 1997. Human alteration of the global nitrogen cycle: sources and consequences. Ecological Applications 7:737-50.

Volkenborn N, Meile C, Polerecky L, Pilditch CA, Norkko A, Norkko J, Hewitt JE, Thrush SF, Wethey DS, Woodin SA. 2012. Intermittent bioirrigation and oxygen dynamics in permeable sediments: an experimental and modeling study of three tellinid bivalves. Journal of Marine Research 70:794-823.

Volkenborn N, Polerecky L, Wethey DS, Woodin SA. 2010. Oscillatory porewater bioadvection in marine sediments induced by hydraulic activities. Limnology and Oceanography 55:1231-47.

Wall LG, Tank JL, Royer TV, Bernot MJ. 2005. Spatial and temporal variability in sediment denitrification within an agriculturally influenced reservoir. Biogeochemistry 76:85111.

Webb AP, Eyre BD. 2004. The effect of natural populations of the burrowing and grazing soldier crab (Mictyris longicarpus) on sediment irrigation, benthic metabolism and nitrogen fluxes. Journal of Experimental Marine Biology and Ecology 309:119.

Yazdani Foshtomi M, Braeckman U, Derycke S, Sapp M, Van Gansbeke D, Sabbe K, Willems A, Vincx M, Vanaverbeke J. 2015. The link between microbial diversity and nitrogen cycling in marine sediments is modulated by macrofaunal bioturbation. PLoS ONE 10:e0130116. 